\title{
Ezra Vogel, Deng Xiaoping and the Transformation of China,
}

Cambridge, MA, and London, The Belknap Press of Harvard University Press, 2011, 876 pp.

Jean-François Huchet

Translator. N. Jayaram

\section{(2) OpenEdition}

\section{Journals}

Electronic version

URL: http://journals.openedition.org/chinaperspectives/6543

DOI: 10.4000/chinaperspectives.6543

ISSN: 1996-4617

\section{Publisher}

Centre d'étude français sur la Chine contemporaine

\section{Printed version}

Date of publication: 1 September 2014

Number of pages: 58-59

ISSN: 2070-3449

\section{Electronic reference}

Jean-François Huchet, «Ezra Vogel, Deng Xiaoping and the Transformation of China, », China

Perspectives [Online], 2014/3 | 2014, Online since 01 January 2017, connection on 22 September 2020 URL : http://journals.openedition.org/chinaperspectives/6543; DOI : https://doi.org/10.4000/ chinaperspectives.6543

This text was automatically generated on 22 September 2020

(c) All rights reserved 


\title{
Ezra Vogel, Deng Xiaoping and the Transformation of China,
}

\author{
Cambridge, MA, and London, The Belknap Press of Harvard University \\ Press, 2011, 876 pp.
}

\section{Jean-François Huchet}

Translation : N. Jayaram

1 Harvard University professor Ezra Vogel is one of the few major American Asia experts who have a deep knowledge of both contemporary China and Japan. His works on Japan, Japan as Number One: Lessons for America (1979), and on China, One Step Ahead in China: Guangdong under Reform (1989), have impressed generations of students as well as political and economic decision-makers and transformed contemporary Asia's image among the Western public.

2 His biography of Deng Xiaoping has similar ambitions. Reflecting on a subject that could "help Americans understand key developments in Asia" in the early twentyfirst century (Preface, p. xi), he declares unhesitatingly: "The biggest issue in Asia is China, and the man who most influenced China's modern trajectory is Deng Xiaoping"

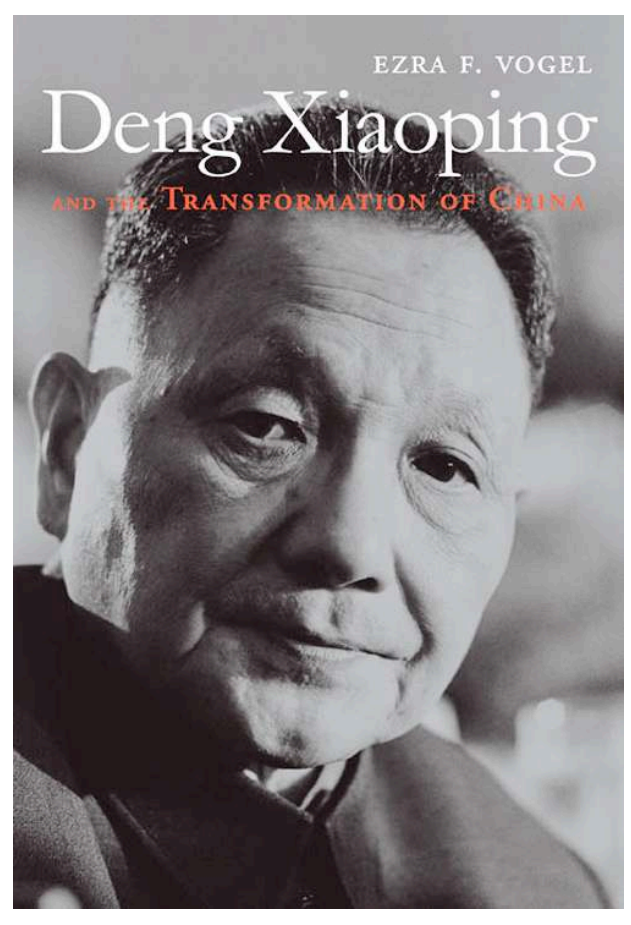
(p. xi). From this certainty stem both the qualities and criticism that can be raised about this book.

3 There already are many biographies on Deng in English: by Harrison E. Salisbury (1992), Ruan Ming (1992), Richard Evans (1994), Benjamin Yang (1998), and Michael Marti (2002), as well as special issues of journals devoted to contemporary China, including The China Quarterly (1993) 
and China Perspectives (1997), from which Vogel has drawn generously. But Vogel's biography of the "Little Helmsman" is to date the most accomplished and comprehensive. Unlike previous biographies, he has profited from the passage of time since Deng's death in 1997 and has been able to draw upon several works in Chinese published in recent years on Deng's life and public activities. There are, of course, new editions of the Chronicles of Deng Xiaoping's Thoughts' for the1904-1974 period, as well as those covering 1974-1997, published in 2009 and 2004 respectively by the CCP Central Document Research Office. Although very formal, these collections (nearly 1,400 pages for the two volumes combined) help furnish some important details regarding Deng's public activities, especially between 1949 and 1978. But Vogel has also been able to consult several recent works of historians, Chinese journalists, and, crucially, former colleagues of Deng who have published accounts of their own direct roles in activities alongside the Little Helmsman, especially two works of Yu Guanyuan published in 2004 and 2005. ${ }^{2}$ Moreover, he conducted hundreds of hours of interviews with Deng's family members, first and second circle collaborators, and Party historians, as well as foreign leaders and ambassadors who had dealings with China since the 1960s. All told, these interviews represent years of effort from 2006 to 2010, and a quick review of footnotes indicates their relevance to almost the whole of Deng's life.

4 The book's most interesting contributions, as against previous works, concern the eras of the Cultural Revolution (1966-1976), the Hua Guofeng interregnum (from Mao's death in September 1976 until December 1978), and the period when economic reforms were being launched - 1978-1984. Not that the rest of the book is uninteresting, but other publications have largely covered the period during which Deng is completely identified with China's history, rendering it less original.

5 For instance, Vogel's book has brought out new elements on the period of internal exile (near Nanchang City in Jiangxi Province) between October 1969 and February 1973, when Deng worked in a tractor spare parts factory. It brings out the extent to which a good deal of Deng's determination to transform China had its origins in this period. Banished from Beijing and having no political role, Deng could see the extent of Maoism's ravages, and during long solitary walks he ruminated over his strategy for change (pp. 52-57).

6 This is likewise the case for the period of Deng's return to work in February 1973 until April 1976, when Mao again removed him from power on accusations of organising popular demonstrations after Zhou Enlai's death. Vogel shows how Deng had to constantly steer prudently through decisions faced with checks and suspicions on the part of Mao's sycophants, especially his wife Jiang Qing. He throws light on Deng's working method during this period, which he never abandoned. Deng masked his intentions and aims with respect to the dominant ideology. He got his speeches vetted by Party intellectuals close to his thinking so as to avoid any charge of revisionism and to render them acceptable to Mao and those surrounding him. Deng was reputed (even criticised by Mao) for his pragmatism in the early 1960s. In 1961, Deng backed Liu Shaoqi, then the regime's No. 2, who violently criticised Mao over the Great Leap Forward's impact and who advocated a more realistic approach to agriculture, industry, and education. But Deng's actions during this period continued to rest on Marxist-Leninist beliefs. From the mid-1970s onward, and especially after Mao's death, Deng set about tweaking communist ideology. He lent ideological trappings to the Party's Left at crucial moments $(1979,1984,1989$, and 1992) when "capitalist drift in economic reforms" were at issue by professing principles and slogans that sounded more and more hollow and divorced from China's economic realities. It was this method that helped Deng promote his economic agenda. First in 1978 and then in 1992, he led China towards a new economic system 
where no communist party had ventured (end of planning, private property, stock exchanges, and private entrepreneurs in the Party), to the extent of creating a completely schizophrenic situation as regards Marxist-Leninist-Maoist dogma. However, as Vogel agilely shows, this matters little: rid of Maoists while preserving all the trappings of the Founding Father, Deng found it more important to develop China and also... to ensure the Party's survival.

Many other interesting points in Vogel's account covering the 1979-1980 period concern Deng's management style, his choice of confidants, the administration's functioning, and the preparations for Party leaders' succession after his generation's passing (Chapters 12 and 13, pp. 349-393), showing that Deng neglected no aspect. In the ideological arena, despite criticisms of Mao, he avoided the trap of Khrushchev-style report and de-Stalinisation, as he knew that he needed the ideological cement and Mao's image to tighten his grip on the CCP's ranks. He also avoided a personality cult. He surrounded himself with much younger leaders who demonstrated the ability to resolve the myriad problems China was facing. His choices of $\mathrm{Hu}$ Yaobang, Zhao Ziyang, and Wan Li are well known. But as former secretary general of the CCP secretariat in charge of all administrative matters (1956-1966), Deng knew more than anyone else the importance of choice of personnel. Until his final days he had a say in nominations to the CCP and army leadership. Vogel writes about his management style: "If Mao were like an emperor above the clouds, reading history and novels and issuing edicts, Deng was more like a commanding general, checking carefully to see that his battle plans were properly staffed and implemented" (p. 377). Vogel also describes how, except from in the restricted family circle, Deng avoided familiarity in his dealings and always maintained a certain distance with his interlocutors. From one day to the next, he had no qualms about asking a confidant to resign from his posts if he considered it to be in the nation's interest. He did that with $\mathrm{Hu}$ in 1987 and Zhao in 1989, and threatened Jiang Zemin with a similar fate in 1992 if he did not reboot economic reforms (p. 679).

While this biography gives an account of the extent and reach of economic and social changes in China during the period when Deng enjoyed complete power, in the end it is difficult to distinguish between the leader's actions and the country's history. Of course, it is a difficult exercise given that Deng's history is so enmeshed with that of China. For instance, his decision to crush the student movement in the spring of 1989 , or even his southern tour in early 1992, took all of China in an irreversible direction. Nevertheless, the extent of the transformation cannot be credited to one man. Despite cautionary notes over this crucial issue early in the last chapter of the book (Chapter 24, p. 693), Vogel offers a series of transformations as having been guided and directed by Deng: the building of a nation open to the outside world, a modern meritocracy, a CCP headed by team leadership, the passage from a rural society to an urban one, and the bureaucracy's dynamism in the local economy. Even so, and despite Deng's leadership qualities, these changes are far beyond the capacity and responsibility of a single man.

Similarly, Deng's darker side, his failures and the negative consequences of his actions, have been largely ignored in the book. However, in the last chapter, by way of conclusion, Vogel invokes a series of issues under the heading "Challenges for Deng's Successors" (p. 711): endemic corruption, curtailment of freedoms, environmental pollution, and challenges to the Party's legitimacy. All of these issues, dismissed in two pages - negative consequences and limits to Deng's public action - deserve a more meticulous analysis so as to afford a more balanced view of Deng individually. More generally, Deng's responsibility for the veritable absence of political reform during his reign (especially the 1979 "Democracy Wall" and the 
1989 crisis over the student movement) is dealt with superficially. All this unfortunately limits the book's reach.

But Vogel has mainly sought to show that Deng succeeded where all other generations of modernising leaders floundered for more than 150 years, making him one of the most important personalities in Chinese history over the past two centuries and of world history from the latter half of the twentieth century to the start of the twenty-first. Moreover, Deng's imprint on the current Party regime is still alive. Despite the limitations of Vogel's exercise, this imposing biography (nearly 900 pages) is bound to serve as a work of reference for a Western public seeking to understand how China has been able to transform as deeply and rapidly as it has done since the late 1970s.

\section{NOTES}

1. Zhonggong zhongyang wenxian yanjiushi (CCP Central Document Research Office), Deng Xiaoping nianpu (Chronicle of Deng Xiaoping's Thoughts), Beijing, Zhongyang wenxian chubanshe, 2004, 2009.

2. An economist and director from 1975 of the State Council Political Research Office and of the Economic Research Institute under the all-powerful former State Planning Commission (before it was renamed the National Development and Reform Commission in 1998), Yu Guanyuan was closely engaged in overseeing the publication of Deng's historic speeches at the Third Plenum of the Eleventh Party Central Committee in December 1978, which definitively sealed his wresting of power from Hua Guofeng and the launch of the reform and opening policy. Yu was one of Zhao Ziyang's close advisors on economic reforms during the 1980 s.

\section{AUTHORS}

\section{JEAN-FRANÇOIS HUCHET}

Jean-François Huchet is Professor at INALCO-Langues'O, Paris (jean-francois.huchet@inalco.fr). 